\title{
Heavy metals in soil and vegetables grown with municipal wastewater in Lahore
}

\author{
A. Hamid ${ }^{1 *}$, A. Mushtaq ${ }^{1}$, R. Nazir ${ }^{2}$ and S. Asghar ${ }^{1}$ \\ ${ }^{I}$ Department of Environment Science, Kinnaird College for Women, 93 Jail Road, Lahore, Pakistan \\ ${ }^{2}$ Applied Chemistry Research Centre, Pakistan Council for Scientific \& Industrial Research (PCSIR) Laboratories, Ferozepur \\ Road, Lahore 54600, Pakistan
}

\begin{abstract}
Heavy metals contamination of fruits and vegetables as a consequence of wastewater irrigation is most important concern today. Present study measures heavy metals concentration $(\mathrm{Cr}, \mathrm{Cu}$ and $\mathrm{Pb})$ in soil and vegetable samples collected from agriculture area around four major drains of Lahore (Hudiara drain, BabuSabu drain, Chota Ravi drain and Kharak drain). Results show that concentration of $\mathrm{Cu}, \mathrm{Cr}$ and $\mathrm{Pb}$ in soil samples were in compliance with WHO and EU standards, with an average of $2.221 \pm 1.184,5.314 \pm 1.0511 \mathrm{and} 3.864 \pm 1.6095 \mathrm{mg} / \mathrm{kg}$ respectively. $\mathrm{Cu}$ contentin vegetablesranged from $0.4-18.9 \mathrm{mg} / \mathrm{Kg}$ (average of $4.11 \pm 6.639 \mathrm{mg} / \mathrm{kg}$ ), was within limits while Cr in Lady Finger, from Chota Ravi drain area, was $13.2 \mathrm{mg} / \mathrm{Kg}$ which is higher than permissible limit $(2.4 \mathrm{mg} / \mathrm{Kg})$. While Pb concentration in vegetables samples varied between $0.7-8.1 \mathrm{mg} / \mathrm{Kg}$ (Mean $2.329 \pm 2.592 \mathrm{mg} / \mathrm{kg}$ ), which was also higher than the standard $(0.3 \mathrm{mg} / \mathrm{Kg})$.
\end{abstract}

Keywords: Heavy metals; Drains; Contamination; Soil; Vegetables

\section{Introduction}

Industrial and municipal wastewater application for agricultural produce contaminates soil and crops with heavy metals and subsequently poses risk to humans and animals. According to an estimate about 20 million hectares of land worldwide is utilizing wastewater for irrigation with $10 \%$ of the total world's population being dependent upon wastewater irrigated food (Corcoran et al., 2010). Likewise, in Pakistan increased demand of food, coupled with scarcity of water, has compelled a greater reliance on use of wastewater for agriculture purposes, with only $2 \%$ water undergoing some treatment before use in irrigation.

The Lahore district drainage system,comprising eight main and 75 tributary drains, has become ultimate disposal locations for industrial and municipal effluents. Two hundred and seventy one industrial units release an estimated 281.6 cusec untreated effluent into the irrigation canals and drains (IPD, 2008) which is ultimately released into River Ravi, within a stretch of nearly $65 \mathrm{~km}$ (WASA, 2007) with the consequence that River Ravi quality has been termed as detrimental for fish and other aquatic life propagation (Akhtar and Mohammad, 2012). Characterization of wastewater samples of drains of Lahore indicates varied concentrations of important parameters of special concern as regards irrigation water quality (Hamid et al., 2013). Earlier, Afzal et al. (2000) has carried out similar study to demonstrate the high pollution levels of Hudiara drain. Discharge of untreated industrial effluents without treatment and its subsequent use in agriculture results in contamination of soil and vegetation and cause toxic effects on crops and vegetables imparting major detrimental impacts on human health. A large number of industries discharge heavy metals as a significant part of their effluents and wastes that enter into surface water sources with the consequence that their manifold; these pose severe impacts and persist in the ecosystem for years (Khattak, 2014). Metals like cadmium (Cd), mercury (Hg), cobalt $(\mathrm{Co})$, lead $(\mathrm{Pb})$, copper $(\mathrm{Cu})$, nickel $(\mathrm{Ni})$, chromium $(\mathrm{Cr})$, and zinc $(\mathrm{Zn})$ are recognized as metals of immediate concern (WHO, 2010). Estimates reveal that heavy metal pollution has produced adverse impacts on soil, fruits and vegetable quality and requires utmost attention (Abii and Okorie, 2011; Sobukola et al., 2010; Sharma et al., 2007; Ismail et al., 2011; Khan et al., 2008; 
Jimoh et al., 2012; Nazemi, 2012; Perveen et al., 2012; Tasrina et al., 2015; Delbari and Kulkarni, 2013; Najam et al., 2015). Vegetables are an important constituent of diet. Comparison of vegetables, fruits and other grain crops shows that heavy metals are largely accumulated in the edible parts of vegetables (Mapanda et al., 2005). Vegetables absorb and store high quantity of these harmful metals and become source of health problems when ingested by humans and animals (Alam et al., 2003; Sobukola et al., 2010). Elevated concentrations of $\mathrm{Cd}, \mathrm{Cu}, \mathrm{Co}$ and $\mathrm{Pb}$ in food stuff are basis of diseases such as bone cancer, high prevalence of upper intestinal cancer, reproductive effects, hypertension and renal failure (Turkdogan et al., 2003). Long term exposure with these toxic elements, even at insignificant levels, causes noxious effects for humans and other living beings. Being nonbiodegradable in nature, persistent in environment and potential bioaccumulation, these metals lead to severe hazards once these enter the bodies of living organisms (Shahid et al., 2015a). Many reports suggest that the continued ingestion of food contaminated with heavy metals can damage liver, nervous, cardiovascular, kidney and/or causing cancers (Jarup, 2003). Extensive evidence of health hazards due to intake of vegetables grown in sewage irrigated water has been reported (Avci, 2012; Ghosh et al., 2012; Wang et al., 2012; Weldegebriel et al., 2012; Xue et al., 2012). Iqbal et al. (2016) carried out a study in Pakistan to assess the concentrations of heavy metals in irrigation water, soil and vegetables, their transfer factors and human health risk. Similar study was conducted by Khan et al. (2013) to evaluate heavy metals in and around Lahore district and analysis revealed that metal concentration were higher when compared with WHO applicable limits. Similarly, Hamid et al. (2016) studied heavy metal contamination of vegetables and soil of Ruhidrain area and their likely health hazards and concluded that $\mathrm{Pb} \mathrm{Cd}, \mathrm{Fe}, \mathrm{Cu}, \mathrm{Zn}$ and $\mathrm{Cr}$ were found in higher concentrations in selected samples.

In view of the present issue of contamination of food, the current study was designed to determine the concentration of selected heavy metals $(\mathrm{Cu}, \mathrm{Cr}$, and $\mathrm{Pb})$ in soil and vegetables that were cultivated by using waste water of major drains of Lahore city.

\section{Materials and methods}

\section{Sampling locations}

Four major drains of Lahore were selected. These included Babu Sabu drain (74.250001667, 31.5205556), Hudiara drain (74.350195278, 31.3835308), Chota Ravi (74.296235,
31.605436) and Kharak drain (74.256196, 31.51328). Soil (top soil TS, subsoil SS) and vegetable samples (being grown there) were collected from each site. Figure $1(a, b)$ illustrates the sampling locations.

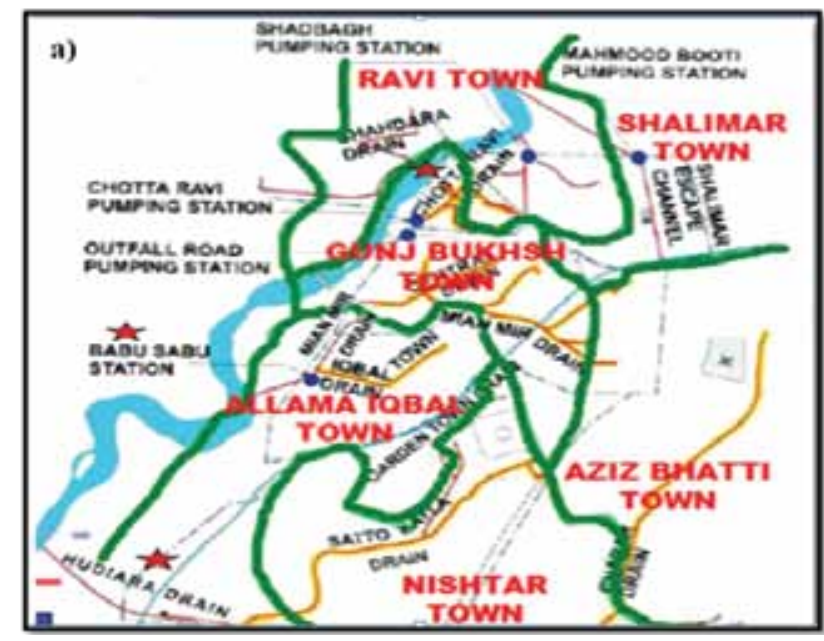

Source: Irrigation and power department, 2008

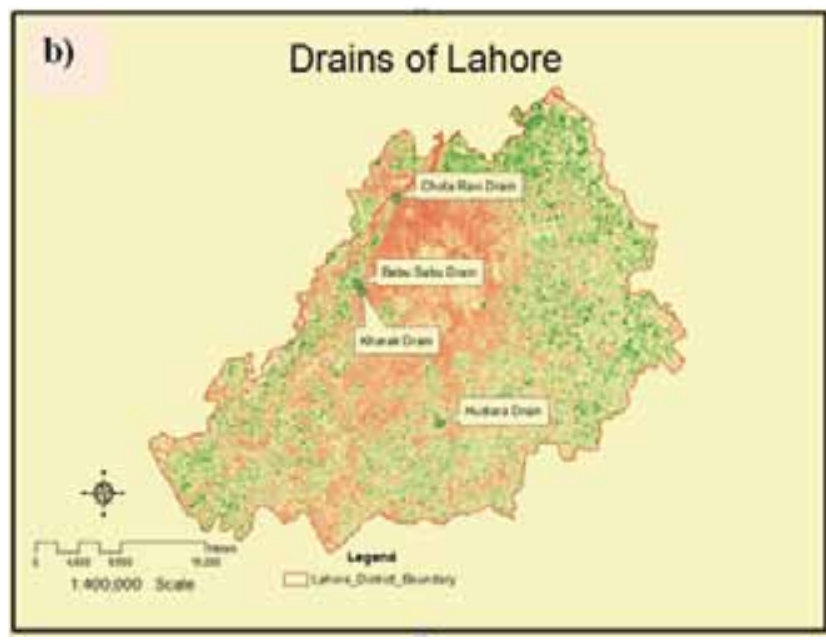

Source: Google Earth map

Fig. 1. (a,b) Map of the Lahore drainage and study area locations

\section{Collection of vegetables and soil samples}

Six different vegetable samples, which included bottle gourd (Lagenaria siceraria), spinach (Spinacia oleracea), egg plant (Solanum melongena), lady finger (Abelmoschus esculentus), pilak (locally grown vegetation/ a type of fodder), tomato (Solanum lycopersicum), and soil samples 
(top soil and sub soil) were collected from selected drains, following sampling protocols and great care to avoid any kind of contamination (Ramteke et al., 2016). Clean air tight plastic bags were used for the collection of these soil and vegetables samples.

\section{Soil sample preparation}

$100 \mathrm{~g}$ of each collected soil sample (TS, SS) was first air dried followed by oven drying at $120^{\circ} \mathrm{C}$ for $3-4 \mathrm{hrs} .10 \mathrm{~g}$ of each dried soil sample was digested using $50 \mathrm{ml}$ of aqua regia solution. The samples' solution were heated to boiling and allowed to simmer for 5-6 hr. After cooling, samples were filtered using Whattman 1 filter paper. After washing twice with $5 \mathrm{ml}$ distilled water, the filtrate along with washings was transferred to $50 \mathrm{ml}$ measuring flask. The volume of filtrate was made up to mark (Ramteke et al., 2016) and solutions were analyzed for $\mathrm{Cu}, \mathrm{Cr}$ and $\mathrm{Pb}$ (USEPA Method 3050).

\section{Vegetable samples preparation}

Six different types of vegetable samples were collected from the fields cultivated with drains' wastewater. The vegetables were washed with distilled water, air dried and chopped into small pieces. Approximately $80-100 \mathrm{~g}$ of these chopped air dried vegetable samples were taken in petri dishes and oven-dried at $70^{\circ} \mathrm{C}$ for $3-4 \mathrm{hrs}$. The dried vegetables were then transferred to beaker and digested with $50 \mathrm{ml}$ of aqua regia solution. The samples' solution were heated to boiling and allowed to simmer for 1-2 hr followed by filtration using Whattman 1 filter paper. In each case, the filter paper was washed twice with $5 \mathrm{ml}$ distilled water and the filtrate along with washings was transferred to $50 \mathrm{ml}$ measuring flask (Taghipour and Mosaferi, 2013; Ramteke et al., 2016). The volume of filtrate was made up to mark and solutions were analyzed to measure concentrations of $\mathrm{Cu}, \mathrm{Cr}$ and $\mathrm{Pb}$ using atomic absorption spectrophotometer (Buck Model 210 VGP).

\section{Results and discussion}

The average results of metal analysis of soil and vegetable samples are given in Tables I and II respectively. Statistical analysis (maximum, minimum, mean value and standard deviation) for heavy metals concentration in vegetables and soil samples was also calculated (Table III).

A total of 7 (TS and SS) samples were analyzed and found to be within the limits (Table I). It is obvious that the concentration of $\mathrm{Cu}, \mathrm{Cr}$ and $\mathrm{Pb}$ were meeting European
Union and WHO's allowed concentrations for metals in soil. This is similar to other studies carried out at Rawalpindi and Peshawar in which heavy metal concentration in soil was also

Table I. Heavy metals concentration in soil samples

\begin{tabular}{ccccc}
\hline Area & $\begin{array}{c}\text { Soil } \\
\text { Sample }\end{array}$ & $\begin{array}{c}\mathbf{C u} \\
\mathbf{m g} / \mathbf{K g}\end{array}$ & $\begin{array}{c}\mathbf{C r} \\
\mathbf{m g} / \mathbf{K g}\end{array}$ & $\begin{array}{c}\mathbf{P b} \\
\mathbf{m g} / \mathbf{K g}\end{array}$ \\
\hline \multirow{2}{*}{ BabuSabu Drain } & $\mathrm{TS}$ & 2.3 & 4.6 & 4.9 \\
& $\mathrm{SS}$ & 4.8 & 6.7 & 6.9 \\
Hudiara Drain & $\mathrm{TS}$ & 1.95 & 6 & 1.95 \\
& $\mathrm{SS}$ & 1.3 & 5.6 & 3.4 \\
Chota Ravi Drain & $\mathrm{SS}$ & 1.5 & 4.3 & 3.4 \\
& $\mathrm{TS}$ & 2.0 & 6.1 & 2.8 \\
Kharak Drain & $\mathrm{TS}$ & 1.7 & 3.9 & 3.7 \\
& Safe Limits & $* 140$ & $* 150$ & $* 300$ \\
& & $* * 100$ & & $* * 84$ \\
\hline
\end{tabular}

$\mathrm{TS}=$ top soil, $\mathrm{SS}=$ sub soil

*EU (2002), **WHO (2006)

Table II. Heavy metals concentration in vegetables grown by using irrigation water of drains and their comparison with WHO/FAO standards

\begin{tabular}{lclccc}
\hline \multicolumn{1}{c}{ Area } & $\begin{array}{c}\text { Sample } \\
\text { No. }\end{array}$ & $\begin{array}{c}\text { Vegetable } \\
\text { Sample }\end{array}$ & $\begin{array}{c}\mathbf{C u} \\
\mathbf{m g} / \mathbf{K g}\end{array}$ & $\mathbf{C r}$ & $\begin{array}{c}\mathbf{P b} \\
\mathbf{m g} / \mathbf{K g}\end{array}$ \\
\hline \multirow{3}{*}{ BabuSabu Drain } & 2 & Spinach & 0.6 & 0.6 & 1.0 \\
& 3 & Egg plant & 1.2 & 1.2 & 1.6 \\
Hudiara Drain & 4 & Tomatle gourd & 0.4 & 1.7 & 1.0 \\
Chota Ravi & 5 & Lady finger & 4.1 & 13.2 & 8.1 \\
Drain & & & & & \\
Kharak Drain & 6 & Lady finger & 2.3 & 1.7 & 1.9 \\
& 7 & Pilak & 18.9 & 0.8 & 2.0 \\
*WHO/FAO, & & & 40 & 2.3 & $0.05-0.3$ \\
**EU standards & & & & & \\
\hline
\end{tabular}

* WHO/FAO (2007), **EU (2006)

found to be within safe limits (Latif et al., 2008; Perveen et al., 2012). Lahore soil samples in another study (Khan et al., 2013) showed $\mathrm{Cu}$ and $\mathrm{Pb}$ concentrations in soil in the range of $1.06-5.42 \mathrm{mg} / \mathrm{kg}$ and $2.11-36.88 \mathrm{mg} / \mathrm{kg}$ respectively. Although concentrations of $\mathrm{Cu}, \mathrm{Cr}$ and $\mathrm{Pb}$ were below the 
Table III. Statistical analysis for heavy metal concentration in the vegetable and soil samples (mg/kg)

\begin{tabular}{ccccccc}
\hline Heavy & \multicolumn{3}{c}{ Vegetable Samples } & \multicolumn{3}{c}{ Soil Samples } \\
\hline Metals & $\begin{array}{c}\text { Maximum } \\
\text { value }\end{array}$ & $\begin{array}{c}\text { Minimum } \\
\text { value }\end{array}$ & Mean \pm SD & Maximum & Minimum & Mean \pm SD \\
& 18.9 & 0.4 & $4.11 \pm 6.639$ & 4.8 & 1.3 & $2.221 \pm 1.184$ \\
$\mathrm{Cu}$ & 13.2 & 0.6 & $2.943 \pm 4.542$ & 6.7 & 3.9 & $5.314 \pm 1.0511$ \\
$\mathrm{Cr}$ & 8.1 & 0.7 & $2.329 \pm 2.592$ & 6.9 & 1.95 & $3.864 \pm 1.6095$ \\
$\mathrm{~Pb}$ & & & & & &
\end{tabular}

limits, these metals are uptaken to different extent by different plants and are translocated to vegetables and fruits grown in that area. Wastewater use for irrigational purposes is reported to cause heavy metal magnification in plants i.e. heavy metals goes to plants without retaining in soil (Achakzai et al., 2011).

From the results of vegetable samples analysis ( Table II), it is observed that concentration of $\mathrm{Cu}$ ranged from $0.4-18.9$ $\mathrm{mg} / \mathrm{Kg}$ with Mean $\pm \mathrm{SD}$ value $4.11 \pm 6.639 \mathrm{mg} / \mathrm{kg}$ which was within safe limit (40 mg/Kg) of EU (2006), in all vegetables samples. Chromium concentration in vegetables ranged from $0.6-13.2 \mathrm{mg} / \mathrm{Kg}$ (Average $2.943 \pm 4.542$ $\mathrm{mg} / \mathrm{kg}$ ) and was exceeding the permissible levels given by $\mathrm{WHO} / \mathrm{FAO}$ and EU $(2.3 \mathrm{mg} / \mathrm{kg})$. The maximum chromium content $(13.2 \mathrm{mg} / \mathrm{Kg})$ was found in lady finger plant grown at Chota Ravi drain area; other plants such as eggplant, tomato, spinach and pilak also had trace amounts of metals but very high level of chromium in lady finger would be due to absorption capacity and ability of the plant. Chromium absorbs rapidly in soil but retain there for short interval because it goes to the other medium such as plants. Oliveira (2012) reported that the level of heavy metal concentration vary with parts of the plant as most of the plants have higher quantity of heavy metals in roots and stems; however their quantity lowers down in the leaves. Many studies in Pakistan have reported $\mathrm{Cr}$ in soil in permissible range of $100-150 \mathrm{mg} / \mathrm{Kg}$ with global mean soil concentration of 60 $\mathrm{mg} / \mathrm{Kg}$ (Waseem et al., 2014). While vegetables grown on soils irrigated with drain water showed $\mathrm{Cr}$ concentration above the tolerable ranges (Perveen et al., 2012).

According to the results, $\mathrm{Pb}$ in vegetables samples varied between $0.7-8.1 \mathrm{mg} / \mathrm{kg}$ with mean $2.329 \pm 2.592 \mathrm{mg} / \mathrm{kg}$. Lead levels in vegetables were also not in compliance with $\mathrm{WHO} / \mathrm{FAO}$ and EU limits $(0.05-0.3 \mathrm{mg} / \mathrm{Kg})$. This is in agreement with other study (Khan et al., 2010) which reports $\mathrm{Pb}$ levels in vegetables in Gilgit, Pakistan in the range of
0.03-44 mg/Kg. Similarly, Farooq et al. (2008) also reports $\mathrm{Pb}$ concentration as $27.49 \mathrm{mg} / \mathrm{kg}$ and $15.58 \mathrm{mg} / \mathrm{kg}$ in edible and leafy parts of vegetables respectively, with $83 \%$ vegetable samples (edible part) contaminated with $\mathrm{Pb}$ content higher than EU (2006) limits.

The results of present study are also consistent with earlier study by Hamid et al. (2016) which also reported $\mathrm{Cu}, \mathrm{Cr}$ and $\mathrm{Pb}$ at compliance levels in soil samples while elevated concentration were detected in selected vegetables.

Based on current study results, the trends of $\mathrm{Cu}, \mathrm{Cr}$ and $\mathrm{Pb}$ in selected vegetables are as follows:

$\mathrm{Cu}=$ Pilak $>$ Ladyfinger $>$ Tomato $>$ Eggplant $>$ Spinach $>$ Bottle gourd

$\mathrm{Cr}=$ Ladyfinger $>$ Bottle gourd $>$ Tomato $>$ Eggplant $>$ Pilak $>$ Spinach

$\mathrm{Pb}=$ Ladyfinger $>$ Pilak $>$ egg plant $>$ Bottle gourd $=$ Spinach $>$ Tomato

\section{Conclusion}

It can be concluded that vegetables grown along four major drains are contaminated with metals i.e. $\mathrm{Cu}, \mathrm{Cr}$ and $\mathrm{Pb}$ in varying amounts. In soil samples $\mathrm{Cu}, \mathrm{Cr}$ and $\mathrm{Pb}$ are detected but their concentration are within applicable permissible limits whereas concentration of $\mathrm{Cr}$ and $\mathrm{Pb}$ is high in vegetables samples. Application of wastewater for irrigation has the potential to accumulate high level of heavy metals in human due to consumption of these vegetables.

\section{References}

Abii TA and Okorie DO (2011), Assessment of the level of heavy metals $(\mathrm{Cu}, \mathrm{Pb}, \mathrm{Cd}$ and $\mathrm{Cr})$ contamination in four popular vegetables sold in urban and rural markets of Abia State Nigeria, Continental, Journal Water Air and Soil pollution 2(1): 42-47. 
Achakzai A, Bazai Z and Kayani S (2011), Accumulation of Heavy Metals by Lettuce (Lactuca Sativa L.) Irrigated with different levels of wastewater of Quetta City, Pak. J. Bot. 43(6): 2953-2960.

Afzal S, Ahmad I, Younas M, Zahid DM, Atique HMK, Ijaz A and Ali K (2000), Study of Water Quality of Hudiara Drain, India-Pakistan, Environ Int. 26(1-2): 87-96.

Akhtar S and Mohammad N (2012), Impact of Water Quality on Aquatic Life in River Ravi, Pakistan, Journal of Nature Environment and Pollution Technology 11(2): 219-224.

Alam MGM, Snow ET and Tanaka A (2003), Arsenic and heavy metal contamination of vegetables grown in Santa village, Bangladesh, Sci. Total Environ. 308: 83-96.

Avci H (2012), Trace metals in vegetables grown with municipal and industrial wastewaters, Toxicological and Environmental Chemistry 94: 1125-1143.

Chauhan G (2014), Toxicity study of metals contamination on vegetables grown in the vicinity of cement factory, International Journal of Scientific and Research Publications 4(11): 1-8.

Corcoran E, Nellemann C, Baker E, Bos R, Osborn D and Savelli H (2010), Sick Water? The central role of wastewater management in sustainable development, A Rapid Response Assessment, United Nations Environment Programme, UN-HABITAT, GRID-Arendal.

Delbari SA and Kulkarni KD (2013), Determination of heavy metal pollution in vegetables grown along the roadside in Tehran- Iran, Scholars Research Library Annals of Biological Research 4(2): 224-233.

European Union (EU) (2002), Heavy Metals in Wastes, European Commission on Environment.

European Union (EU) (2006), Commission regulation (EC) No. 1881/2006, setting maximum levels for certain contaminants in foodstuffs, Official Journal of the European Union 364: 5-24.

Farooq M, Anwar A and Rashid U (2008), Metal contents in vegetables grown on an Industrial area, Pak J. Bot. 40(5): 2099-2106.

Ghosh AK, Bhatt MA and Agrawal HP (2012), Effect of longterm application of treated sewage water on heavy metal accumulation in vegetables grown in Northern
India, Environmental Monitoring and Assessment 184: 1025-1036.

Hamid A, Zeb M, Mehmood A, Akhtar S and Saif S (2013), Assessment of Wastewater Quality of Drains for Irrigation, Journal of Environmental Protection 4: 937-945.

Hamid A, Riaz H, Akhtar S and Ahmad RS (2016), Heavy Metal Contamination in Vegetables, Soil and Water and Potential Health Risk Assessment, Am-Euras. J. Agric. \& Environ. Sci. 16(4): 786-794.

IPD (2008), An Atlas: Surface Water Industrial and Municipal Pollution in Punjab, Irrigation and Power Department, Directorate of Land Reclamation Punjab, pp 1-132.

Iqbal HH, Taseer R, Anwar S, Mumtaz M and Shahid N (2016), Human health risk assessment: heavy metal contamination of vegetables in Bahawalpur, Pakistan, Bulletin of Environmental Studies 1(1): 10-17.

Ismail F, Anjum MR, MamonAN and Kazi TG (2011), Trace metal contents of vegetables and of Hyderabad Retail Market, PJN 10(4): 365-372.

Jarup L (2003), Hazards of heavy metal contamination, British Medical Bulletin 68(1): 167-182.

Jimoh TO, Ndamitso MM, AbdullahiSH and Bankole MT (2012), Determination of copper, iron and lead levels in selected vegetables obtained from the three main markets, in Minna, North Central Nigeria, AJFS 6(23): 554-559.

Khan A, Javid S, Muhmood A, Mjeed T, Niaz A and Majeed A(2013), Heavy metal status of soil and vegetables grown on peri-urban area of Lahore district, Soil Environ. 32(1): 49-54.

Khan S, Aijun L, Zhang S, Hu Q and Zhu YG (2008), Accumulation of polycyclic aromatic hydrocarbons and heavy metals in lettuce grown in the soils contaminated with long-term wastewater irrigation, $J$. Hazard Mater. 152: 506-515.

Khan S, Rehman S, Khan AZ, Khan MA and Shah MT (2010), Soil and vegetables enrichment with heavy metals from geological sources in Gilgit, Northern Pakistan, Ecotox Environ Safe. 73(7): 1820-1827.

Khattak IM (2014), Determination of heavy metals $(\mathrm{Cu}, \mathrm{Cd}$, $\mathrm{Zn}$, Ni \& $\mathrm{Pb}$ ) levels in untreated waste effluents of industries in Quetta, Sci. Int (Lahore) 26(1): 301-305. 
Latif MI, Lone MI and Khan KS (2008), Heavy metals contamination of different water sources, soils and vegetables in Rawalpindi area, Soil \& Environment 27(1): 29-35.

Mapanda F, Mangwayana EN, Nyamangara J and Giller KE (2005), The effects of long-term irrigation using water on heavy metal contents of soils under vegetables, Agri. Ecosys. Environ 107: 151-156.

Najam S, Nawaz R, Ahmad S, Ehsan N, Khan MM and Nawaz HM (2015), Heavy Metals Contamination of Soils and Vegetables Irrigated with Municipal Wastewater: A Case Study of Faisalabad, Journal of Environmental and Agricultural Sciences 4: 6-10.

Nazemi S (2012), Concentration of Heavy metal in edible vegetables widely consumed in Shahroud, the North East of Iran, J Appl Environ Biol Sci. 2(8): 386-391.

Oliveira H (2012), Chromium as an Environmental Pollutant: Insights on Induced Plant Toxicity, International Journal of Botany, $\mathrm{p} 8$.

Perveen S, SamadA, Nazif W and Shah (2012), Impact of Sewage water on vegetables quality with respect to heavy metals in Peshawar, Pakistan, Pak. J. Bot. 44(6): 1923-1931.

Ramteke S, Sahu LB, Dahariya SN, Patel SK, Blazhev B and Matini L (2016), Heavy metal contamination of vegetables, Journal of Environmental Protection 7: 996-1004.

Shahid M, Dumat C, Pourrut B, Abbas G, Shahid N and Pinelli E (2015a), Role of metal speciation in lead-induced oxidative stress to Viciafaba roots, Russian Journal of Plant Physiology 62(4): 448-454.

Sharma KR, AgrawalM and Marshall F (2007), Heavy Metal Contamination of Soil and Vegetables in Suburban Areas of Varanasi, India, Ecotoxicology and Environmental Safety 66(2): 258-266.

Sobukola OP, Ademiran OM, Dairo AA and Kajihausa OE (2010), Heavy metal levels of some fruits and vegetables from selected markets in Lagos Nigeria, African Journal of Food Science 4(2): 389-393.

Taghipour H, Mosaferi M (2013), Heavy Metals in the Vegetables Collected from Production Sites, Health Promotion Perspectives 3(2): 185-193.

Tasrina RC, Rowshon A, Mustafizur AMR, Rafiqul I and Ali MP (2015), Heavy Metals Contamination in
Vegetables and its Growing Soil, J. Environ Anal Chem. 2: 142.

Turkdogan MK, Fevzi K, Kazim K, Ilyas T and Ismail U (2003), Heavy metals in soil, vegetables and fruits in the endemic upper gastrointestinal cancer region of Turkey, J. Environ. Toxicol. Pharmacol. 13: 75-179.

Wang YC, Qiao M, Liu YX and Zhu YG (2012), Health risk assessment of heavy metals in soils and vegetables from wastewater irrigated area, Beijing-Tianjin city cluster, China, Journal of Environmental SciencesChina 24: 690-698.

WASA (2007), Presentation on the Initiative Taken in WASA Lahore Regarding Benchmarking of UWSS, Water and Sanitation Agency, Lahore.

Waseem A, Arshad J, Iqbal F, Sajjad A, Mehmood Z and Murtaza G (2014), Pollution status of Pakistan: A retrospective review on heavy metal contamination of water, soil and vegetables, Biomed. Res Int. p 29.

Weldegebriel Y, Chandravanshi BS and Wondimu T (2012), Concentration levels of metals in vegetables grown in soils irrigated with river water in Addis Ababa, Ethiopia, Ecotoxicology and Environmental Safety 77: 57-63.

WHO (2010), Guideline for drinking water Quality recommendation (Vol.1), World Health Organization, Geneva.

WHO/FAO (2007), Joint FAO/WHO Food Standard Programme Codex Alimentarius Commission 13th Session, Report of the Thirty Eight Session of the Codex Committee on Food Hygiene, Houston, TX, USA.

WHO (2006), Guidelines for the safe use of wastewater, excreta and greywater: Wastewater use in agriculture (Vol. II), World Health Organization, Geneva.

Xue ZJ, Liu SQ, Liu YL and Yan YL (2012), Health risk assessment of heavy metals for edible parts of vegetables grown in sewage-irrigated soils in suburbs of Baoding City, China, Environmental Monitoring and Assessment 184: 3503-3513.

Received: 24 January 2017; Revised: 21 March 2017; Accepted: 29 May 2017. 